\title{
Influence of matric potential and substrate characteristics on germination of Nezpar Indian ricegrass
}

\author{
ROBERT R. BLANK AND JAMES A. YOUNG
}

\begin{abstract}
Authors are soil scientist and range scientist, respectively, USDA, Agricultural Research Service, Landscape Ecology of Rangelands Unit, 920 Valley Road, Reno, Nevada 89512.
\end{abstract}

\begin{abstract}
Intact seeds (caryopses) of Indian ricegrass [Oryzopsis hymenoides (R. \& S.) Ricker] are generally reported to exhibit poor germination. The cultivar Nezpar was evaluated to determine if substrate matric potential and substrate physiochemical properties influence germination. Matric potentials ranged from 0 to -1.5 MPa. Substrate variables included: 2 kinds of germination paper, the $A$ horizon of a dune sand, and a commercial washed silica sand. Seeds of Indian ricegrass had low germination $(<5 \%)$ with an oversaturated substrate. Germination increased significantly $(P \leq 0.05$ ) between -0.005 and $-0.10 \mathrm{MPa}$ tension (30 to 70\%), then decreased at more negative matric potentials. As compared with paper substrates, the dune sand showed significantly greater $(P \leq 0.05)$ germination at matric potentials more negative than -0.30 MPa. Standard germination screening procedures, especially at high water contents, do not adequately predict the maximum germination characteristies of Indian ricegrass; thus, substrate matric potential is a critical variable to control in germination tests. Moreover, physiochemical differences among common laboratory germination substrates may lead to significantly different germination responses. Microscopic examination of cross-sections of caryopses suggests the mechanism for reduced seed germination at saturated and oversaturated conditions may be the presence of a void between the lemma and palea which, when water-filled, retards oxygen diffusion to the embryo.
\end{abstract}

Indian ricegrass (Oryzopsis hymenoides) is a component of rangeland plant communities from Manitoba to British Columbia, south to Texas, California, and northern Mexico (Hitchcock 1950). It is often the dominant herbaceous species over vast areas in the driest portions of the temperate deserts of the far western United States (Robertson 1976). This bunchgrass reaches its greatest development on areas of sand-textured soils (Young et al. 1983). In arid areas, Indian ricegrass is often the only grass adapted to sand-and coarse-silt-textured spoils from mining and milling operations.

Use of Indian ricegrass in revegetation has long been hampered by high seed costs associated with harvesting losses due to seed shattering (Jones 1990) and seed dormancy (Huntamer 1934). Dormancy was attributed to both indurate lemmas and paleas and embryo dormancy. The nature of seed dormancy for the species was first described by Huntamer (1934) and has been subject to numerous studies since then (e.g., McDonald and Khan 1977). For several decades, it was considered necessary to scarify seeds of Indian ricegrass before planting (Stoddart and Wilkinson 1938, Plummer and Frischknecht 1952, Zemetra et al. 1983, Young et al. 1985). The potential of damage to Indian ricegrass from acid

Authors wish to thank Ms. Debra Palmquist for assistance in statistical analyses and Ms. Fay Emmerich for laboratory work.

Manuscript accepted 17 June 1991. scarification was noted by Stoddart and Wilkinson (1938) and McDonald and Khan (1983).

Natural establishment of Indian ricegrass plants has been associated with the collection and seed caching activities of heteromyid rodents (McAdoo et al. 1983). Rodents frequently remove the lemma and palea before caching the seeds, effectively removing one form of dormancy. The embryo dormancy of Indian ricegrass has been demonstrated to decrease over time and old seeds have higher germination than younger lots (Robertson 1976). Embryo dormancy can also be overcome with prechill and application of gibberellin (e.g., Young and Evans 1984).

Our purpose was to measure the influence of substrate characteristics and matric potential on the germination of seeds of Indian ricegrass and to evaluate if one form of dormancy could be released through substrate-matric potential manipulations.

\section{Materials and Methods}

Seeds of Indian ricegrass cv. Nezpar (Booth et al. 1980) were obtained from a commercial seed lot and used in all experiments. The company estimated seed viability to be $99 \%$ by the tetrazolium method. Four replications of 25 seeds, arranged in a randomized block design, were used. Seeds were incubated in the dark at $22^{\circ} \mathrm{C}$. The age of seed was 32 months at the beginning of the experiment. Previous work in our lab indicated that this particular seed lot exhibited very high germination, thus, embryo dormancy was assumed to be minimal.

Substrate variables tested were: (a) white cellulose blotter paper sold as nontoxic germination paper (white paper); (b) blue blotter paper with $25 \%$ rag content sold as germination paper (blue paper); (c) sieve-washed commercial silica sand (silica sand); and (d) the A horizon from a natural dune (torripsamment) where Indian ricegrass occurs (dune soil). Moisture release curves, for the substrates, were determined with a pressure membrane apparatus (Richards and Fireman 1943) (Table 1). Germination counts were made at 2-day intervals for 2 weeks. Seeds were considered germinated when the radicle emerged $5 \mathrm{~mm}$ on paper substrates, or when the shoot emerged in mineral substrates. At the end of the experiment, seeds were separated from the mineral substrates and examined. From this examination, percent germination between paper and mineral substrates was at an equivalent basis.

The various air-dry substrates were preweighed and moistened with deionized water to the desired matric potential. For oversaturation, a layer of water was added atop the saturated substrates. The paper substrates were cut into squares that fit plastic petri dishes. The seeds were placed on the media and spaced to fill the entire paper substrate. For the mineral substrates, a large amount of soil was placed in a plastic bucket and an appropriate amount of deionized water was added to reach the desired matric potential. The mineral substrates were added to $400-\mathrm{mL}$ beakers until onefourth to one-half full and lightly compressed. The seeds were 
Table 1. Matric potential-gravimetric water content relationships established with a pressure membrane apparatus for 4 germination substrates.

\begin{tabular}{|c|c|c|c|c|c|c|c|c|c|c|c|c|}
\hline \multirow[b]{2}{*}{ Substrate } & \multicolumn{12}{|c|}{ Matric Potentials (MPa) } \\
\hline & Sat. & -0.005 & -0.01 & -0.033 & -0.1 & -0.2 & -0.3 & -0.4 & -0.6 & -0.8 & -1.0 & -1.5 \\
\hline & $\ldots \ldots$ & & 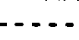 & - & & $--\mathrm{g} \mathrm{kg}_{\mathrm{g}}$ & -1 & C.... & $\ldots$ & $\ldots$ & $\ldots$. & $\ldots$ \\
\hline White paper & 5,400 & 2,160 & 1,380 & 780 & 600 & 530 & 485 & 480 & 430 & 421 & 398 & 390 \\
\hline Blue paper & 2,500 & 1,430 & 1,320 & 1,040 & 740 & 680 & 640 & 620 & 580 & 550 & 520 & 470 \\
\hline Dune sand & 225 & 128 & 86 & 60 & 52 & -1 & - & 40 & 34 & 30 & 28 & 27 \\
\hline Silica sand & 241 & 86 & 51 & 33 & 21 & - & - & 16 & 14 & 13 & 11 & 10 \\
\hline
\end{tabular}

'Not determined

placed on this surface, covered with approximately $3 \mathrm{~cm}$ of the substrate, and compressed lightly. The petri dishes and beakers were covered with loose-fitting lids and placed in large plastic bags for incubation. Moisture loss was minimal throughout the experiment as determined by before and after weights.

After the incubation period had expired, a portion of the germinated plants and nongerminated seeds were fixed in formalin and acetic acid and reserved for later microscopic examination.

The nutrient status of the various substrates, before and after the germination trials, was determined by a $\mathrm{CaCl}_{2}$ extract. Ten grams of substrate was mixed with $35 \mathrm{~mL}$ of $1.5 \mathrm{~g} \mathrm{~kg}^{-1} \mathrm{CaCl}_{2}$ solution and shaken for $30 \mathrm{~min}$. Extracts were centrifuged, then filtered through a $0.22-\mu \mathrm{m}$ nylon filter. Anions and monovalent cations in the extracts were determined by ion chromatography with detection by suppressed conductivity (Weiss 1986). Particle size distribution of the mineral substrates was determined using established procedures (Gee and Bauder 1986).

To gauge the effects of soaking time on the germination of Nezpar Indian ricegrass, seeds were soaked in deionized nonaerated water. At particular times, seeds were removed from the water and placed on white germination paper at $-0.01 \mathrm{MPa}$ matric potential. Incubation conditions and measurement of germination were as stated above.

Cross-sections of seeds were obtained by fixing seeds in $10 \%$ glutaraldehyde solution and impregnating with a commercial resin. The hardened resin was polished until cross-sections of seeds appeared.

Osmotic potentials of the substrates at selected matric potentials were calculated as follows. The molarities of the $\mathrm{CaCl}_{2}$ extractable ions were summed. Cation or anion imbalances were corrected by adding additional molarity to obtain electroneutrality. The corrected molarities were transformed for each matric potential knowing the ratio of water weight to substrate weight for each substrate and matric potential. The final calculated molarities were used to solve the Van't Hoff equation (osmotic potential $=n R T$ ) where $n$ is equal to molarity, $R$ is the universal gas constant $\left(0.0082 \mathrm{dm}^{3} \mathrm{~atm}\right.$ $\mathrm{K}^{-1} \mathrm{~mol}^{-1}$ ) and $\mathrm{T}$ was $298^{0} \mathrm{~K}$. Ideal solutions were assumed.

A one-way analysis of variance was used to statistically compare percent germination among substrates at a particular matric potential. Duncan's New Multiple Range Test at the $P \leq 0.05$ level was utilized as the multiple comparison technique for comparing germination differences among the substrates when a significant F-test $(P \leq 0.05)$ resulted. Quadratic regression equations, with their corresponding confidence intervals, were generated to statistically compare percent germination among matric potentials for a particular substrate and as a function of time of seed soaking. Significant differences $(P \leq 0.05)$ in germination between differing matric potentials or seed soaking times were determined by nonoverlapping confidence intervals about the regression estimates (Evans et al. 1982).

\section{Results and Discussion}

\section{Influence of Matric Potential and Substrate}

Seed germination of Nezpar Indian ricegrass was influenced by both matric potential and germination substrate (Tables 2 and 3 ). The most important result was that slight manipulation of matric potential significantly $(P \leq 0.05)$ enhanced the germination of largely mechanically dormant populations of seeds (dormant under oversaturated conditions). A similar matric potential effect has been reported for Oryzopsis holciformic (Dasberg and Mendel 1971), but we are unaware of any reports on Indian ricegrass.

Table 2. Average percent germination of Nezpar seed after 2 weeks incubation time in the dark at $22^{\circ} \mathrm{C}$ in the experimental substrates at selected matric potentials 1 .

\begin{tabular}{|c|c|c|c|c|c|}
\hline \multirow[b]{2}{*}{$\begin{array}{l}\text { Matric } \\
\text { Potential }\end{array}$} & \multicolumn{5}{|c|}{ Substrate } \\
\hline & $\begin{array}{l}\text { White } \\
\text { Paper }\end{array}$ & $\begin{array}{c}\text { Two } \\
\text { White } \\
\text { Papers }^{2}\end{array}$ & $\begin{array}{l}\text { Blue } \\
\text { Paper }\end{array}$ & $\begin{array}{l}\text { Silica } \\
\text { Sand }\end{array}$ & $\begin{array}{l}\text { Dune } \\
\text { Sand }\end{array}$ \\
\hline$--\mathrm{MPa}-$ & $\ldots$ & 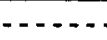 & $-\%=$ & $\ldots$ & $\ldots$ \\
\hline Oversaturated & $16 a$ & $7 \mathrm{~b}$ & $2 b$ & $0 \mathrm{~b}$ & ob \\
\hline saturated & $52 a$ & $44 a$ & $3 b$ & $\mathbf{0 b}$ & $2 b$ \\
\hline-0.005 & $57 a$ & $58 \mathrm{a}$ & $11 \mathrm{~b}$ & $60 a$ & $51 a$ \\
\hline-0.01 & $70 a$ & $70 a$ & $12 b$ & $70 \mathrm{a}$ & $77 \mathrm{a}$ \\
\hline-0.10 & $70 \mathrm{a}$ & $72 \mathrm{a}$ & $11 \mathrm{~b}$ & $77 a$ & $78 a$ \\
\hline-0.20 & 0 & -3 & 6 & - & - \\
\hline-0.30 & 0 & - & 14 & - & - \\
\hline-0.40 & - & - & $15 \mathrm{~b}$ & $35 b$ & $83 a$ \\
\hline-0.60 & - & - & $5 b$ & $4 b$ & $80 \mathrm{a}$ \\
\hline-0.80 & - & - & $4 b$ & $11 b$ & $70 \mathrm{a}$ \\
\hline-1.0 & - & - & $12 \mathrm{a}$ & $\mathrm{Ob}$ & $8 a b$ \\
\hline-1.5 & - & 一 & 3 & 0 & 0 \\
\hline
\end{tabular}

${ }^{1}$ A post hoc multiple comparison test was performed comparing germination results among the different substrates for each matric potential level. Row means followed by the same letters are similar $(P \leq 0.05)$ based on Duncan's New Multiple Range Test. ${ }^{2}$ Seeds placed between 2 white papers.

${ }^{3}$ Not determined.

Germination obtained at oversaturation on white paper ranged from 7 to $16 \%$. Lowering the moisture level to seturation $(5,400 \mathrm{~g}$ of water per $\mathrm{kg}$ of substrate, Table 1$)$ significantly $(P \leq 0.05)$ increased germination on or between sheets of white paper to about $50 \%$ (Table 3). The change from oversaturated to saturated had little or no influence in enhancing germination with mineral substrates; both water contents had poor germination (Table 2).

Inducing a slightly negative matric potential of $-0.005 \mathrm{MPa}$ significantly ( $P \leq 0.05)$ increased germination on most substrates to about $60 \%$ (Tables 2 and 3). Germination of seeds approached $70 \%$ on all substrates at $-0.01 \mathrm{MPa}$ matric potential, except for blue paper (Table 2). At matric potentials more negative than -0.01 $\mathrm{MPa}$, germination was generally higher on mineral substrates than the white paper substrate (Table 2). The dune sand had high rates 
Table 3. Estimated percent germination of Nezpar seed after 2 weeks incubation time in the dark at $22^{\circ} \mathrm{C}$ in the experimental substrates at selected matric potentials. ${ }^{1}$

\begin{tabular}{|c|c|c|c|c|}
\hline \multirow[b]{2}{*}{$\begin{array}{l}\text { Matric } \\
\text { Potential }\end{array}$} & \multicolumn{4}{|c|}{ Substrate } \\
\hline & $\begin{array}{l}\text { White } \\
\text { Paper }\end{array}$ & $\begin{array}{c}\text { Two } \\
\text { White } \\
\text { Papers }^{2}\end{array}$ & $\begin{array}{l}\text { Silica } \\
\text { Sand }\end{array}$ & $\begin{array}{l}\text { Dune } \\
\text { Sand }\end{array}$ \\
\hline - MPa - - & $\ldots \ldots$ & $\ldots \ldots$ & $\ldots$. & $\cdots$ \\
\hline Oversaturated & $16 \mathrm{bc}$ & $6 \mathrm{~b}$ & $5 b c$ & $0 \mathrm{e}$ \\
\hline saturated & $61 \mathrm{a}$ & $56 a$ & $40 a$ & $54 a b c$ \\
\hline-0.005 & $61 \mathrm{a}$ & $57 a$ & $41 \mathrm{a}$ & $56 a b c$ \\
\hline-0.01 & $61 \mathrm{a}$ & $59 a$ & $42 a$ & $58 \mathrm{ab}$ \\
\hline-0.10 & $52 a$ & $73 a$ & $50 a$ & $76 a$ \\
\hline 0.20 & $25 b$ & 3 & - & - \\
\hline 0.30 & $0 c$ & - & - & - \\
\hline-0.40 & - & - & $41 \mathrm{a}$ & $72 a$ \\
\hline-0.60 & -0.20 & - & $30 \mathrm{ab}$ & $60 \mathrm{ab}$ \\
\hline-0.80 & -0.30 & - & $19 b$ & $48 b c$ \\
\hline-1.0 & - & - & $8 b$ & $35 \mathrm{~cd}$ \\
\hline-1.5 & - & - & $O c$ & $4 d$ \\
\hline
\end{tabular}

${ }^{1}$ Regression equation predicted means in columns are not significantly different if followed by the same letter based on overlap of confidence intervals at the $\alpha=0.05$ level.

${ }^{2}$ Seeds placed between 2 white papers

${ }^{3}$ Not determined.

of germination even at a matric potential of $-0.80 \mathrm{MPa}$.

The germination of seeds of Nezpar Indian ricegrass placed on blue germination paper was, in general, significantly ( $P \leq 0.05$ ) lower than the other substrates and not greatly influenced by matric potential (Table 2). The silica sand substrate had a smaller window of germination and showed a greater depression in germination between $-0.10 \mathrm{MPa}$ and $-0.60 \mathrm{MPa}$ than dune sand (Tables 2 and 3).

\section{Nature of Matric Potential and Substrate Influences}

The seed lot of Indian ricegrass that was used in the experiment was highly viable $(99 \%)$ as indicated by tetrazolium testing. The maximum germination obtained through manipulation of matric potential was $83 \%$ (Table 2). We assume because of the high germination obtained, that embryo dormancy was minimal. Oversaturated substrates produced a maximum of $16 \%$ germination making the level of germination enhancement roughly 60 to $70 \%$. That the germination is so influenced by matric potential, is of great biological significance in the germination ecology of Indian ricegrass.

Explanation of the matric potential response involves several considerations. First, seeds in saturated and oversaturated substrates were covered by far more fungal hyphae than seeds at more negative matric potentials. Fungal exudates can reduce seed germination (Abdulla 1970). Moreover, saturated and oversaturated conditions would limit seed aeration. Côme and Tissaoui (1973) reported that wet seed coats reduce $\mathrm{O}_{2}$ transport to the embryo, thereby, reducing seed germination. Dasberg and Mendel (1971) reported experimental evidence which linked poor germination of Oryzopsis holciformic [(M.B.) Richt.] at high moisture contents to low oxygen diffusion through water films around seed coats.

To clarify the mechanism of reduced seed germination at saturated conditions, seeds were soaked in deionized water at $22^{\circ} \mathrm{C}$ in the dark, then germinated on white paper at a matric potential of $-0.01 \mathrm{MPa}$. If fungal exudates were the cause of reduced germination, then soaked seeds covered with fungus should not germinate well when incubated. After 2 days soaking time, most seeds were covered with fungal hyphae. Yet, even after 96 hours of soaking we still obtained a high percentage germination (Table 4), which refutes the fungal mechanism of reduced seed germination. The conjecture that lack of oxygen reduced germination at high water
Table 4. Average percent germination of Nezpar seed after 2 weeks incubation time in the dark $22^{\circ} \mathrm{C}$ on white paper at $-0.10 \mathrm{MPa}$ matric potential subsequent to soaking in nonaeriated water from 0 to 96 hours.

\begin{tabular}{lcc}
\hline \hline Soaking time & Average germination Regression germination \\
\hline Hour & 53 & $50 \mathrm{c}$ \\
1 & 54 & $61 \mathrm{bc}$ \\
3 & 80 & $74 \mathrm{a}$ \\
12 & 79 & $78 \mathrm{a}$ \\
24 & 74 & $78 \mathrm{a}$ \\
48 & 73 & $75 \mathrm{a}$ \\
72 & 73 & $71 \mathrm{ab}$ \\
96 & &
\end{tabular}

${ }^{1}$ Regression equation predicted means in columns are not significantly different if followed by the same letter based on overlap of confidence intervals at the $\alpha=0.05$ level.

contents is supported by the observation that under saturated conditions, the paper germination media had significantly ( $P \leq 0.05$ ) greater germination (Table 2). At saturation, a portion of the seed is exposed to air in the paper media, but in the mineral substrates, seeds are completely covered with wet soil. At oversaturation, seeds placed between 2 white papers had significantly $(P \leq 0.05)$ less germination than seeds placed on top of white paper (Table 2). Reduction in oxygen diffusion to the embryo and endosperm at saturated and oversaturated conditions may be assisted by waterfilled gaps between the lemma and palea (Fig. 1). Such gaps have been demonstrated for the caryopses of other species (McWilliam and Phillips 1971).

The germination substrates differed considerably in levels of $\mathrm{CaCl}_{2}$ extractable compounds (Tables 5 and 6). The key findings to note are high levels of nitrate in dune sand, high levels of ammonia in white paper, the mineralization of nitrate during incubation in the dune soil, and the presence of large quantities of soluble salts in blue paper.

The chemical nature of the seedbed influences germination. Particular chemical compounds can stimulate germination, others can inhibit germination. Given the similarity in particle size distribution between the dune sand and silica sand (Table 5), one might expect similar germination at equivalent matric potentials. Yet, the dune sand generally had significantly $(P \leq 0.05)$ greater germination rates (Table 2). High levels of nitrate in the dune sand before incubation and nitrate mineralized during the incubation period (Tables 5 and 6) may explain the elevated germination rates (Popay and Roberts 1970). However, Huntamer (1934) and Toole (1940) reported no improvement in the germination of Indian ricegrass seeds treated with $\mathrm{KNO}_{3}$.

Ammonium salts can stimulate or inhibit seed germination, and if at high levels, can be toxic to seeds. Levels of ammonia in the white paper, at matric potentials more negative than $-0.01 \mathrm{MPa}$, have been reported to stimulate germination in some seeds (Hendricks and Taylorson 1974).

The osmotic potential, associated with high sodium and sulfate content of the blue paper (Table 5), may have decreased the total soil water potential sufficiently to reduce germination. However, the calculated osmotic potentials of the germination substrates, which were never greater than $-0.04 \mathrm{MPa}$ for any germination substrate, are unlikely to have influenced seed germination.

The physical nature of the substrates may be important in explaining differences in germination response among the substrates. The white and blue paper are composed of minute organic fibers, which assures intimate contact with seeds. In the coarsetextured mineral substrates, seeds are in limited contact with mostly angular quartz and feldspar grains (Collis-George and Sands 1961). The paper substrates more effectively supply water to the imbibing seed than the mineral substrates (Collis-George and 

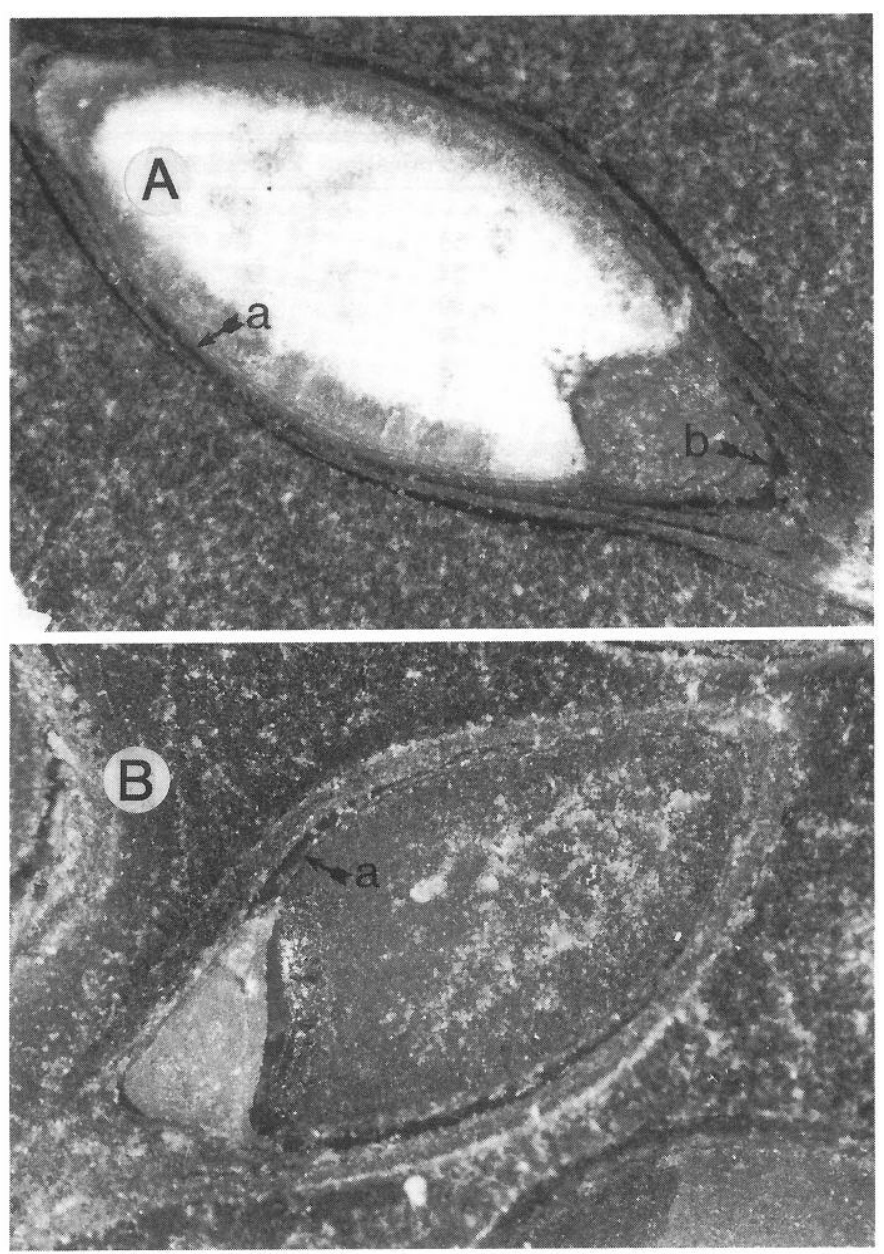

Fig. 1. Photomicrographs of cross-sections of Indian ricegrass. Micrograph $(A)$ is of an untreated seed and $(B)$ is of a seed that had been soaked in deionized water for 2 days. Features to note are the gap between the lemma and palea (a) and between the palea and embryo (b). After 2 days soaking the endosperm has become noticeably darker than the endosperm of fresh seed. This observation implies that physiological changes occur when Indian ricegrass seed are soaked in water, yet, germination does not occur.

Sands 1962) because of greater seed-substrate contact and a high water to substrate mass ratio at a given matric potential. At matric potentials more negative than $-0.3 \mathrm{MPa}$, however, the mineral substrates had higher percent germination than the white germination paper (Table 2). Given the low water to substrate ratio and the extremely low hydraulic conductivities in the mineral substrates at these matric potentials, one might expect the white paper substrate to have higher germination rates. We postulate that a portion of the moisture required for seed germination is obtained via the vapor phase in a moisture saturated soil atmosphere. Seeds in the
Table 6. Calcium chloride extractable nitrate and sulfate of the mineral substrates after 2 weeks incubation time.

\begin{tabular}{rccccc}
\hline \hline & \multicolumn{2}{c}{ Dune Sand } & & \multicolumn{2}{c}{ Silica Sand } \\
\cline { 2 - 3 } \cline { 5 - 6 } Treatment & $\mathrm{NO}_{3}^{-1}$ & $\mathrm{SO}_{4}^{-2}$ & & $\mathrm{NO}_{3}{ }^{-1}$ & $\mathrm{SO}_{4}^{-2}$ \\
\hline & 1.6 & 10.5 & & 0.5 & 6.6 \\
Saturated & 85.2 & 7.5 & & 0.7 & 4.7 \\
$-0.005 \mathrm{MPa}$ & 70.0 & 7.1 & & 2.1 & 5.4 \\
$-0.01 \mathrm{MPa}$ & 80.2 & 6.8 & & 0.9 & 4.6 \\
$-0.1 \mathrm{MPa}$ & 85.6 & 7.0 & & 2.1 & 5.6 \\
$-0.6 \mathrm{MPa}$ & 80.0 & 7.0 & & 1.5 & 5.3 \\
$-0.8 \mathrm{MPa}$ & 64.4 & 6.0 & & 0 & 4.9 \\
$-1.0 \mathrm{MPa}$ & 59.0 & 6.5 & & 0 & 4.2 \\
$-1.5 \mathrm{MPa}$ & & & & &
\end{tabular}

mineral substrates were completely covered and the coarsetextured nature of the substrates assured that most of the seed coat was in contact with the soil atmosphere. Even at $-1.5 \mathrm{MPa}$, the soil atmosphere is nearly saturated with water (Hillel 1982). The petri dishes used for germination of the paper substrates allow for greater mixing with low relative humidity laboratory air, especially during times of seed counting.

This hypothesized mechanism may also explain the observation that Indian ricegrass seeds have more favorable germination when buried at depths $>10 \mathrm{~cm}$ (Kinsinger 1962). When forced by large diurnal temperature shifts, characteristic of desert ecosystems, downward water vapor movement can be of equal magnitude to liquid water movement upward (Rose 1968, Jackson et al. 1973).

\section{Conclusions}

It is clear from our experiments that germination substrates, maintained at saturated and oversaturated conditions, do not adequately model the potential germination response of Indian ricegrass. Determining germination profiles in the laboratory may require that matric potential be incorporated as a variable for some species. Some of the alleged poor germination characteristics of some lots of Indian ricegrass and potentially other species, may have been caused by the presence of excessive amounts of water during germination trials.

The physiochemical properties of substrates influence the germination response of Nezpar Indian ricegrass. The data are inconclusive as to what controls this effect, but researchers should be aware of this phenomenon.

Manipulation of substrate matric potential apparently overcomes mechanical dormancy of Nezpar Indian ricegrass. This may occur because of innate low mechanical dormancy in this seed lot.

\section{Literature Cited}

Abdulla, M.H. 1970. Preliminary study on the influence of fungal metabolites on germination of barley grains. Mycopath. Mycol. Appl. 41:307-313.

Table 5. General chemical and physical characteristics of the substrates.

\begin{tabular}{|c|c|c|c|c|c|c|c|}
\hline \multirow[b]{2}{*}{ Substrate } & \multicolumn{4}{|c|}{$\mathrm{CaCl}_{2}$ Extractable } & \multicolumn{3}{|c|}{ Particle Size Distribution } \\
\hline & $\mathrm{NO}_{3}{ }^{-1}$ & $\mathrm{SO}_{4}^{-2}$ & $\mathrm{Na}^{+1}$ & $\mathrm{NH}_{4}{ }^{+1}$ & Sand & Silt & Clay \\
\hline & $-\cdots-\cdots-$ &.--- & -- & $---\cdot$ & $\ldots \ldots-\ldots$ & $\mathrm{g} \mathrm{kg}^{-1}$ & $\ldots-\ldots$ \\
\hline White paper & 3.3 & 5.4 & 21.6 & 13.5 & & & \\
\hline Blue paper & 7.5 & 42.9 & 72.6 & 4.6 & & & \\
\hline Dune sand & 19.6 & 2.3 & 2.5 & 1.0 & 91.9 & 2.3 & 5.8 \\
\hline Silica sand & 0.5 & 4.0 & 0.5 & $\mathrm{dl}^{1}$ & 95.3 & 1.1 & 3.6 \\
\hline
\end{tabular}

'Below detection limits of instrument. 
Booth, T.D., C.G. Howard, and C.E. Mowry. 1980. 'Nezpar' Indian ricegrass: Description, justification for release, and recommendations for use. Rangelands 2:53 54 .

Collis-George, N., and J.E. Sands. 1961. Moisture conditions for testing germination. Nature 190:367.

Collis-George, N., and J.E. Sands. 1962. Comparison of the effects of the physical and chemical components of soil water energy on seed germination. Australian. J. Agr. 13:575-584.

Côme, D., and T. Tissaoui. 1973. Interrelated effects of imbibition, temperature and oxygen on seed germination, p. 157-168. In: W. Heydecker (ed.) Seed Ecology. The Pennsylvania State Univ. Press, Univ. Park, Penn.

Dasberg, S., and K. Mendel. 1971. The effect of soil water and aeration on seed germination. J. Exp. Bot. 22:992-998.

Evans, R.A., D.A. Easi, D.N. Book, and J.A. Young. 1982. Quadratic response surface analysis of seed-germination trials. Weed Sci. 30:411-416.

Gee, G.W., and J.W. Bauder. 1986. Particle-size analysis, p. 383-411. In: A. Klute (ed.) Methods of Soil Analysis Part 1. Physical and Mineralogical Methods, 2nd ed. No. 9 in Agronomy Series. Amer. Soc. Agron. Madison, Wis.

Hendricks, S.B., and R.B. Taylorson. 1974. Promotion of seed germination by nitrate, nitrite, hydroxylamine, and ammonium salts. Plant Physiol. 54:304-309.

Hillel, D: 1982. Introduction to soil physics. Academic Press, Orlando, Fla. Hitchcock, A.S. 1950. Manual of grasses of the United States. U.S.D.A. M.P. 200

Huntamer, M.Z. 1934. Dormancy and delayed germination of Oryzopsis hymenoides. MS thesis. State College of Washington, Pullman.

Jackson, R.D., B.A. Kimball, R.T. Reginato, and F.S. Nakayama. 1973. Diurnal soil-water evaporation: Time-depth-flux patterns. Soil Sci. Soc. Amer. Proc. 37:505-509.

Jones, T.A. 1990. A viewpoint on Indian ricegrass research: Its present status and future prospects. J. Range Manage. 43:416-420.

Kinsinger, F.E. 1962. The relationship between depth of planting and maximum foliage height of seedlings of Indian ricegrass. J. Range Manage. 15:10-13.

McAdoo, J.K., C.C. Evans, B.A. Roundy, J.A. Young, and R.A. Evans. 1983. Influence of Heteromyid rodents on Oryzopsis hymenoides germination. J. Range Manage. 36:61-64.
McDonald, M.B., Jr., and A.A. Khan. 1977. Factors determining germination of Indian Ricegrass seeds. Agron. J. 69:558-563.

MeDonald, M.B., Jr., and A.A. Khan. 1983. Acid scarification and protein synthesis during seed germination. Agron. J. 75:111-114.

McWilliam, J.R., and P.J. Phillips. 1971. Effect of osmotic and matric potential on the availability of water for seed germination. Australian J. Biol. Sci. 24:423-431.

Plummer, A.D., and N.C. Frischknecht. 1952. Increasing stands of Indian ricegrass. Agron. J. 44:285-289.

Popay, A.I., and E.H. Roberts. 1970. Factors involved in the dormancy and germination of Capsella bursa-pastoris (L.) Medik, and Senecio vulgaris (L.). J. Ecol. 58:103-122.

Richards, L.A., and M. Fireman. 1943. Pressure plate apparatus for measuring moisture sorption and transmission by soils. Soil Sci. 56:395-404.

Robertson, J.H. 1976. The autecology of Oryzopsis hymenoides. Mentzelia $1: 18-21,25-27$.

Rose, C.W. 1968. Water transport in soil with a daily temperature wave. Australian J. Soil Res. 6:45-57.

Stoddart, L.A., and K.J. Wilkinson. 1938. Inducing germination in Oryzopsis hymenoides for range reseeding. Agron. J. 30:763-768.

Toole, V.K. 1940. The germination of seeds of Oryzopsis hymenoides. J. Amer. Soc. Agron. 32:33-41.

Weiss, J. 1986. Handbook of Ion chromatography. Dionex Corp., Sunnyvale, Calif.

Young, J.A., R.A. Evans, and B.A. Roundy. 1983. Quantity of germinability of Oryzopsis hymenoides seeds in Lahontan sands. J. Range Manage. 36:82-86.

Young, J.A., and R.A. Evans. 1984. Germination of seeds of Paloma and Nezpar Indian ricegrass. J. Range Manage. 37:19-21.

Young, J.A., R.A. Evans, and D.A. Easi. 1985. Enhancing germination of Indian ricegrass seeds with sulfuric acid. Agron. J. 77:203-206.

Zemetra, R.S., C. Havstad, and R.L. Cuany. 1983. Reducing seed dormancy in Indian ricegrass [Oryzopsis hymenoides, J. Range Manage. 36:239-241. 